\title{
PERANCANGAN SISTEM INFORMASI PENJUALAN ALAT KESEHATAN DAN KEDOKTERAN BERBASIS WEB PADA PT. SINAR BULAN PURNAMA MEDICAL MAKASSAR
}

\author{
${ }^{1}$ Sitti Fatimah, ${ }^{2}$ Achmad Tabrani
}

${ }^{1,2}$ Sekolah Tinggi Manajemen Informatikan dan Komputer (STIMIK) Dipanegara Makassar

\begin{abstract}
Abstrak
PT Sinar Bulan Purnama Medical merupakan suatu perusahaan yang bergerak dalam bidang penjualan alat-alat kesehatan dan kedokteran yang berlokasi di Kota Makassar Propinsi Sulawesi Selatan tepatnya di Jl. Adhyaksa Baru no. 12 G. Produk yang di jual adalah alat-alat kesehatan dan kedokteran untuk keperluan pribadi maupun untuk keperluan umum seperti pada rumah sakit, klinik, dan instansi-instansi pendidikan yang berkaitan dengan kesehatan. Dalam pelaksanaan proses penjualan dan pemasarannya masih bersifat konvensianal, yaitu proses jual belinya masih harus dilakukan dengan datang dan melihat langsung produk yang ingin di beli konsumen. Proses memasarkannya pun masih dengan menggunakan selebaran dan info iklan pada radio dan beberapa media cetak lokal. Oleh karena itu, kami mencoba untuk membuat suatu rancangan program penjualan yang terkomputerisasi. Lebih menarik dan mengglobal dari segi pemasaran serta mudah untuk diaplikasikan dan digunakan dalam mengolah dan menghasilkan informasi yang efektif dan efisien tentang jual beli alat-alat kesehatan dan kedokteran.
\end{abstract}

Kata kunci : $\quad$ Perancangan Sistem Informasi, Penjualan Alat Kesehatan Dan Kedokteran, PT Sinar Bulan Purnama Makassar

\section{PENDAHULUAN}

Dengan melihat betapa pentingnya eksistensi dari teknologi yang ada dan sistem informasi yang berkembang, mereka pun berusaha untuk merancang suatu sistem yang dapat melancarkan usaha dan bisnisnya agar dapat diakses oleh orang lain dan digunakan masyarakat umum yang membutuhkan informasi tersebut. Penjualan dengan menggunakan teknologi internet atau yang lebih dikenal dengan istilah E-Commerce (Electronic Commerce), berkembang semakin marak dengan munculnya perusahaan-perusahaan yang menawarkan barang dagangannya di internet.

PT. Sinar Bulan Purnama Medical yang mengolah usaha bisnis dibidang penjualan alat-alat kesehatan dan kedokteran sudah sepantasnya memanfaatkan fasilitas sistem komputerisasi dan teknologi internet dalam mengolah informasi dan transaksi untuk kelancaran bisnis usahanya. Salah satu usaha peningkatan efektifitas kerja dalam hal ini dibutuhkan sebuah sistem aplikasi yang berbasis jaringan online dengan efisiensi penggunaan berbagai sumber daya daalam bentuk website. Sehingga metode perancangan sistem penjualan berbasis web diharapkan dapat menghasilkan informasi yang lebih baik dari sistem sebelumnya.

PT. Sinar Bulan Purnama Medical merupakan suatu perusahaan yang bergerak dalam bidang penjualan alat-alat kesehatan dan kedokteran. Dalam pelaksanaan proses penjualan dan pemasarannya masih belum sepenuhnya menghasilkan manfaat secara optimal karena diolah secara konvensional atau manual, seperti informasi produk yang ditawarkan, baik lama maupun yang terbaru. Persediaan stok yang masih ada ditoko dan harganya. Sistem pembelian dan pemesanannya yang masih mengharuskan pembeli untuk datang langsung ke tempat penjualan dan melakukan transaksi terhadap produk yang ingin dibelinya. Dan proses memasarkannya pun yang masih dengan menggunakan selebaran dan informasi iklan pada radio dan beberapa media cetak lokal. Hal ini yang menjadi hambatan karena pemasaran produk pada kota tempat perusahaan tersebut berada membutuhkan biaya transportasi yang cukup murah, beda halnya pada pembeli yang berada diluar kota baik dalam propinsi maupun propinsi lain diluar pulau yang membutuhkan biaya transportasi yang cukup tinggi untuk datang langsung bertransaksi ke tempat pembelian produk.

Berdasarkan latar belakang tersebut di atas, maka penulis tertarik untuk menelitinya dan melakukan perancangan terhadap sistem penjualan yang berbasis Web pada PT. Sinar Bulan Purnama Medical serta mencoba memberikan alternatif baru terhadap sistem informasi pemasarannya kepada masyarakat. 


\section{METODE PENELITIAN}

\section{Waktu dan Lokasi Penelitian}

Penelitian ini dilaksanakan pada bulan Desember 2009 sampai dengan bulan Februari 2010, bertempat di PT. SINAR BULAN PURNAMA MEDICAL yang beralamat di Jl. Adhyaksa Baru No. 12 G Makassar, Propinsi Sulawesi Selatan dengan Nomor Telepon 0411-5792699 / 2560456.

\section{Jenis Penelitian}

Penelitian Kepustakaan ( Library Research)

Yaitu pengumpulan data dengan cara membaca buku mengenai literatur yang bersifat ilmiah sesuai dengan pembahasan dan mencari beberapa referensi dari situs-situs di internet yang ada hubungannya dengan materi yang akan di bahas.

Penelitian Lapangan (Field Research)

Yaitu kegiatan yang dilakukan dengan cara mengumpulkan data secara langsung ke lokasi penelitian dan memfokuskan pada objek yang akan di teliti sebagai data mekanisme penjualan sesuai pembahasan.

Pada kegiatan penelitian ini, penulis menggunakan beberapa metode yang dijadikan sebagai cara pengumpulan data yang dibutuhkan, yaitu:

\section{Metode Wawancara (Interview)}

Wawancara memungkinkan peneliti untuk melakukan tanya jawab seputaran objek yang akan diteliti sebagai bahan data yang di perlukan dalam perancangan yang akan di buat. Dalam hal ini peneliti melakukan wawancara secara langsung kepada pengelola perusahaan itu mengenai metode penjualan dan pemasaran yang sedang berjalan.

\section{Metode Observasi}

Observasi adalah pengamatan langsung terhadap suatu kegiatan yang sedang dilakukan. Di sini peneliti melakukan pengamatan secara langsung dalam kegiatan-kegiatan penjualan di perusahaan untuk mengetahui metode yang sedang berjalan.

\section{Alat dan Bahan Penelitian}

\section{Alat Penelitian}

\section{Software}

- Windows Xp Service Pack 2 sebagai sistem operasi

- Apache Friends XAMPP (Basis Package) versi 1.7.3

- Macromedia Dreamweaver versi 8.0.0.2734

- Adobe Photoshop CS3

\section{Hardware}

- Satu (1) unit Netbook merk BYON

\section{Alat Desain}

- Bagan alir dokumen.

- Diagram Arus Data.

- Kamus data.

- Flowchart dan Flowgraph.

\section{Bahan Penelitian}

Dalam penelitian ini digunakan bahan-bahan sebagai berikut :

1. Data produk.

2. Daftar harga.

3. Data stok barang.

4. Draf data pelanggan.

5. Profil Perusahaan.

6. Gambar-gambar produk dan tempat perusahaan.

\section{Metode Pengujian Perangkat Lunak}

Metode pegujian perangkat lunak yang akan digunakan adalah pengujian White Box dengan langkah-langkah sebagai berikut:

1. Terlebih dahulu dibuat flowchart program dalam bentuk modular.

2. Buat flowgraph setiap modul yang merupakan transformasi dari flowchart

3. Hitung Cyclomatic Complexity, Region, dan Independent path dari flowgraph

4. Jika Cyclomatic Complexity $=$ Region $=$ Independent Path akan disimpulkan bahwa modul sudah bebas dari kesalahan logika.

\section{Langkah-langkah Penelitian}

Adapun langkah - langkah penelitian yang digunakan oleh peneliti adalah sebagai berikut:

1. Pengumpulan data dan observasi.

2. Analisis sistem.

3. Perancangan sistem.

4. Pengujian sistem.

5. Implementasi sistem.

\section{ANALISIS DAN PERANCANGAN SISTEM}

Tahap analisis sistem merupakan tahap yang penting, tahap ini akan berpengaruh pada tahap selanjutnya, sebab analisis sistem merupakan penguraian dari suatu sistem yang utuh ke dalam bagian atau entitas-entitas yang terlibat di dalam suatu sistem, yang bertujuan untuk mengevaluasi permasalahan, kesempatan, hambatan yang terjadi dan kebutuhan yang diharapkan sehingga dapat diusulkan perbaikan atau perancangan suatu sistem yang baru.

Untuk lebih jelasnya mengenai gambaran sistem penjualan dan pemasaran yang sedang berjalan dan sistem yang diusulkan pada PT.Sinar Bulan Purnama Medical, dapat dilihat pada bagan alir dokumen berikut: 


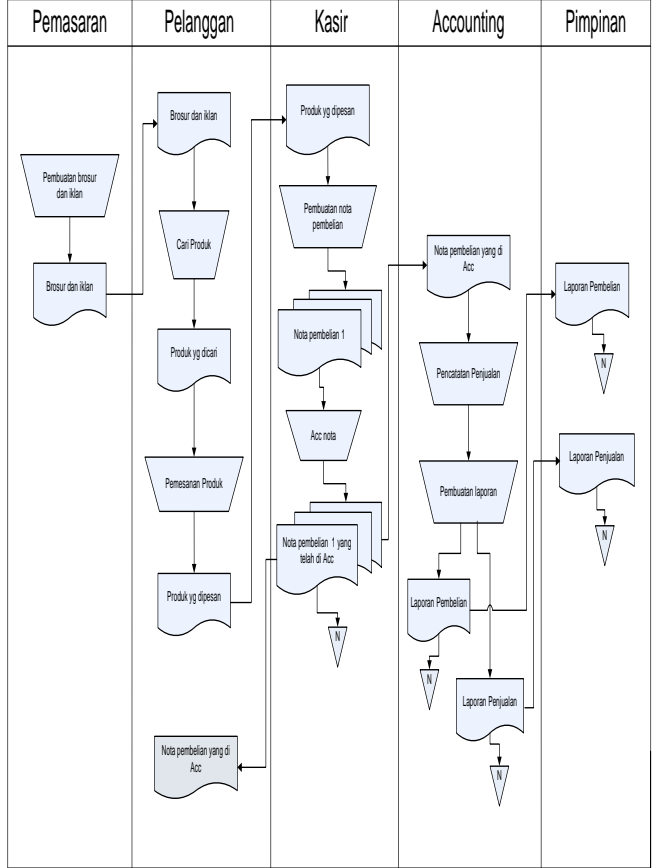

Gambar 1. Bagan Sistem yang Berjalan

\begin{tabular}{|c|c|c|c|c|c|c|}
\hline Pelanggan & \multicolumn{2}{|c|}{ Admin } & Gudang & Supplier & Marketing & Pimpinan \\
\hline$\Leftrightarrow$ & 然 & & $=$ & $-\infty$ & pomian & \\
\hline sinter & Jimante & & $\therefore$ & 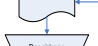 & 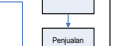 & \\
\hline enest & & & and & $=$ & & \\
\hline & & & Ostaresg & $=$ & 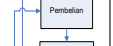 & \\
\hline$x=$ & ons & & & & $=$ & \\
\hline sentat. & & & & & $=$ & \\
\hline$=$ & & 然= & 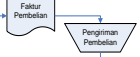 & semensar. & 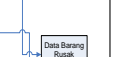 & $x=$ \\
\hline aregyond & & & $=$ & & $=$ & $\dot{n}$ \\
\hline sim & . & & 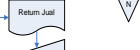 & & Fin & 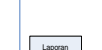 \\
\hline$=$ & $=$ & & some & & & $=$ \\
\hline
\end{tabular}

Gambar 2. Bagan Sistem yang Diusulkan

\section{Rancangan Sistem}

Rancangan sistem bertujuan untuk memberikan gambaran secara umum kepada user tentang sistem yang baru. Rancangan sistem secara umum merupakan persiapan dari rancangan sistem secara terinci. Rancangan sistem secara umum mengidentifikasi komponen-komponen sistem informasi yang akan didesain secara terinci.

\section{Diagram Konteks}

Diagram konteks merupakan pola penggambaran yang berfungsi untuk memperlihatkan interaksi sistem informasi tersebut dengan lingkungan di mana sistem tersebut ditempatkan. Penggambaran interaksi untuk sistem yang di usulkan dapat dilihat pada gambar 3 dibawah ini,

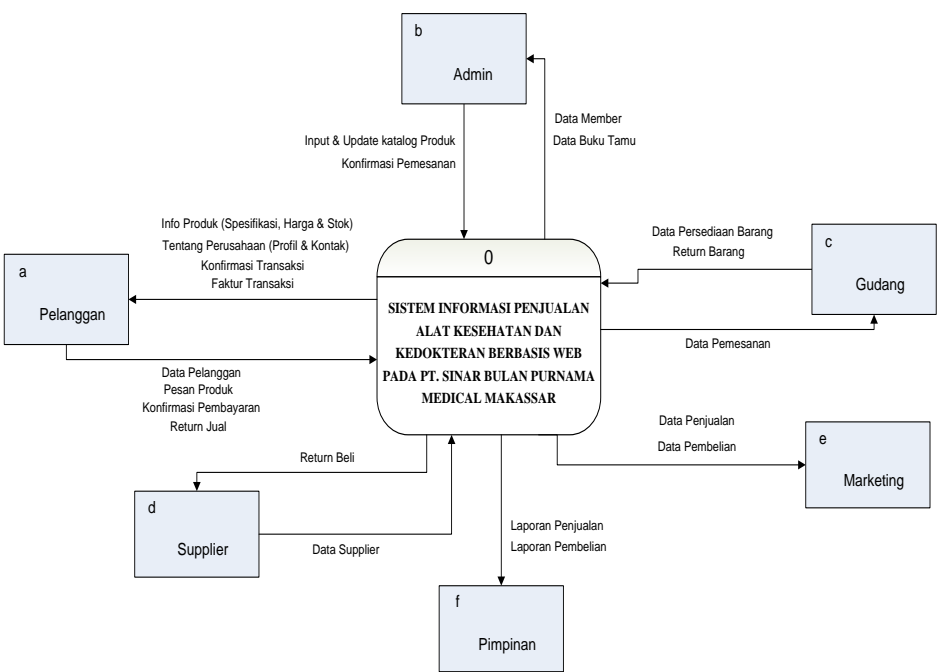

Gambar 3. Diagram konteks

\section{Diagram Berjenjang}

Diagram berjenjang merupakan diagram yang menggambarkan urutan-urutan proses yang terdapat atau yang telah digambarkan pada diagram konteks sistem. Diagram berjenjang digunakan untuk mempersiapkan penggambaran DAD ke levellevel yang lebih bawah lagi secara berjenjang. Maka akan tampak seperti pada gambar 4 berikut :

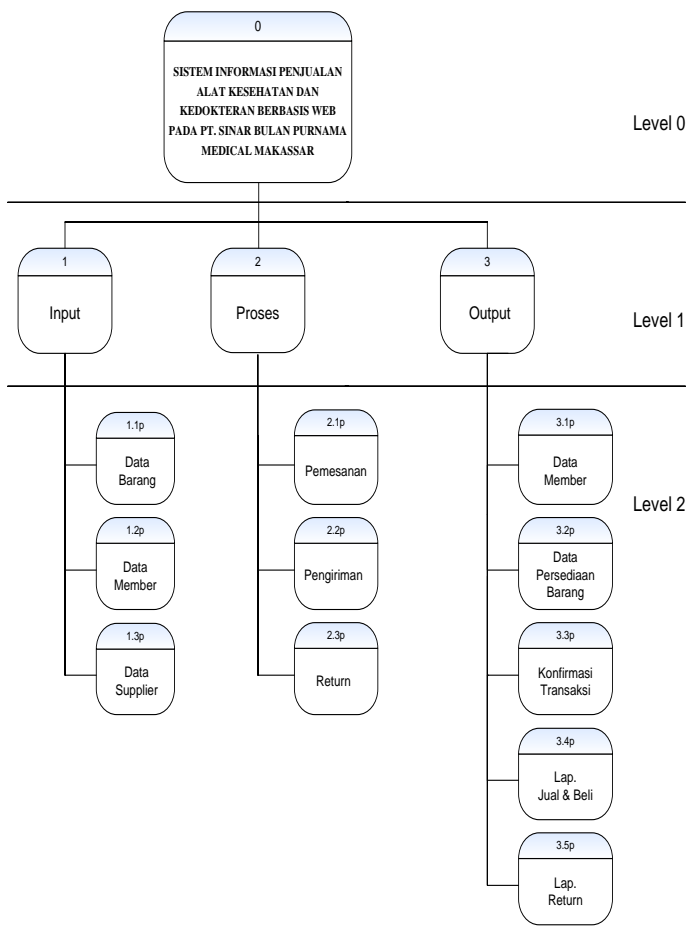

Gambar 4. Diagram Berjenjang

\section{Diagram Arus Data (DAD) Level 1.}

Adapun Arus Data Level 1 dari perancangan sistem informasi penjualan berbasis web Pada PT. 
Sinar Bulan Purnama Medical adalah sebagai berikut

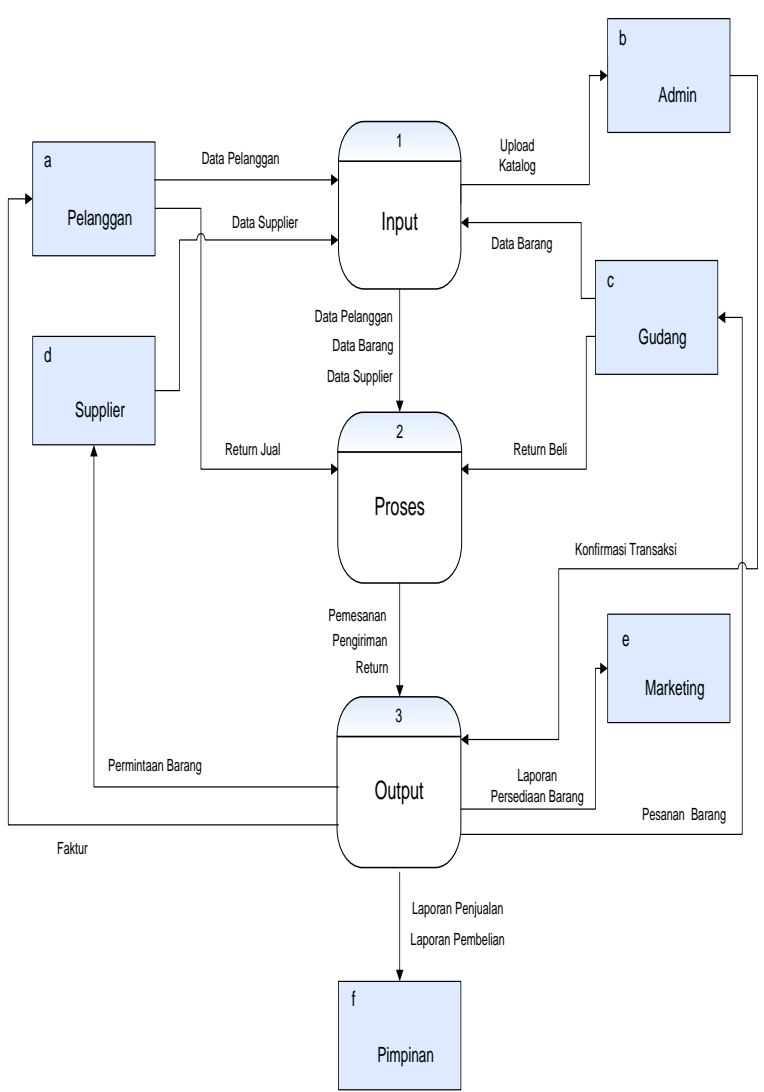

Gambar 5. Diagram Alur Data (DAD) level 1

\section{Diagram Arus Data (DAD) Level 2 (Proses Input)}

Adapun Arus Data Level 2 (Proses Input) dari perancangan sistem informasi penjualan berbasis web Pada PT. Sinar Bulan Purnama Medical adalah sebagai berikut :

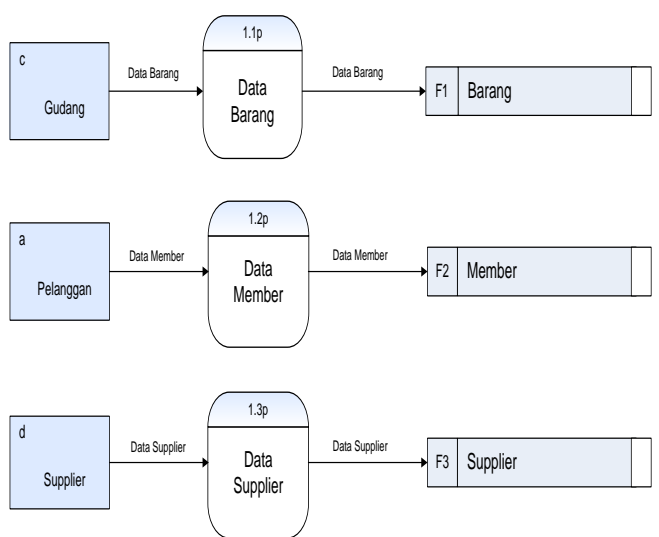

Gambar 6. Diagram Alur Data (DAD) Level 2 (Proses Input)
Diagram Arus Data (DAD) Level 2 (Proses Proses) Adapun Arus Data Level 2 (Proses Prose) dari perancangan sistem informasi penjualan berbasis web Pada PT. Sinar Bulan Purnama Medical adalah sebagai berikut :

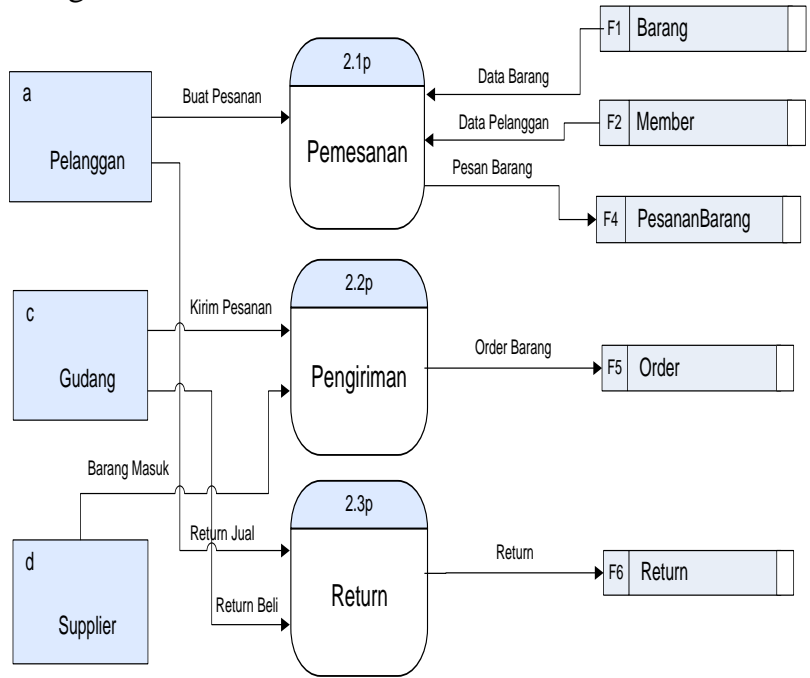

Gambar 7. Diagram Alur Data (DAD) Level 2 (Proses Proses)

\section{Diagram Arus Data (DAD) Level 2 (Proses Output)}

Adapun Arus Data Level 2 (Proses Output) dari perancangan sistem informasi penjualan berbasis web Pada PT. Sinar Bulan Purnama Medical adalah sebagai berikut :

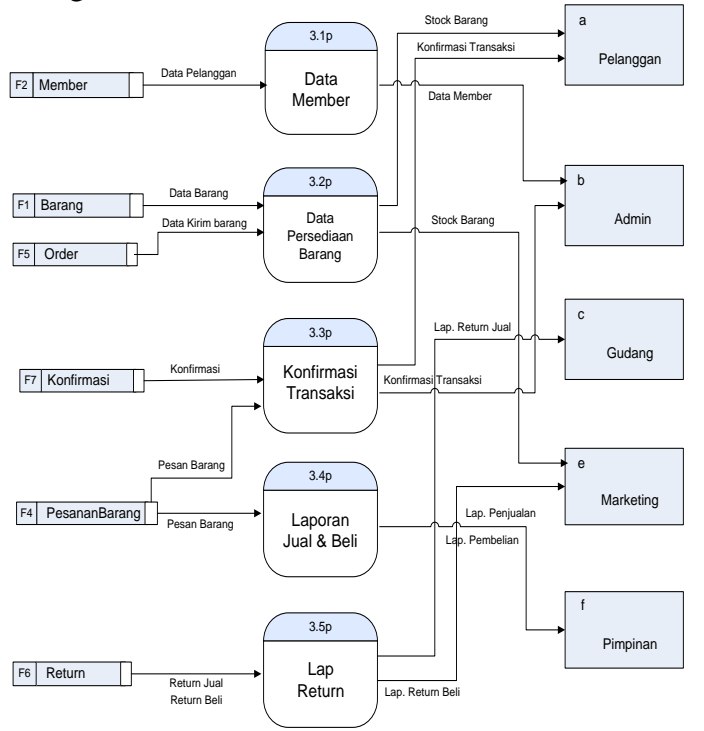

Gambar 8. Diagram Alur Data (DAD) Level 2 (Proses Output)

\section{Kamus Data}

Kamus data atau Data Dictionary (DD) adalah katalog fakta tentang data dan kebutuhankebutuhan informasi dalam suatu sistem informasi. 
Dengan menggunakan kamus data, analisis dapat mendefenisikan data yang mengalir di sistem dengan lengkap. Pada tahap analisis, kamus data digunakan sebagai alat komunikasi antara analisis sistem dengan pemakai sistem tentang data yang mengalir di sistem. Pada tahap perancangan sistem, kamus data digunakan untuk merancang input, merancang laporan-laporan database.

Adapun kamus data yang di gunakan dalam perancangan sistem informasi penjualan berbasis web Pada PT. Sinar Bulan Purnama Medical adalah sebagai berikut :

Tabel 1. Data Admin

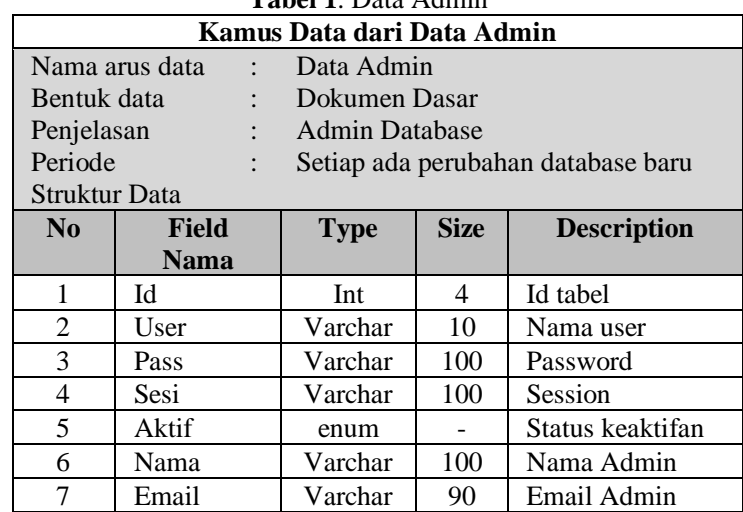

Tabel 2 Data Barang

\begin{tabular}{|c|c|c|c|c|}
\hline \multicolumn{5}{|c|}{ Kamus Data dari Data Barang } \\
\hline \multicolumn{2}{|c|}{$\begin{array}{l}\text { Nama arus data } \\
\text { Alias } \\
\text { Bentuk data } \\
\text { Penjelasan } \\
\text { Periode } \\
\text { Struktur Data }\end{array}$} & \multicolumn{3}{|c|}{$\begin{array}{l}\text { Data Barang } \\
\text { Katalog Produk } \\
\text { Dokumen Dasar } \\
\text { Data barang lama maupun baru } \\
\text { Setiap ada penambahan barang } \\
\text { baru }\end{array}$} \\
\hline No & Field Nama & Type & Size & Description \\
\hline 1 & id & Int & 11 & Id tabel \\
\hline 2 & kd_barang & Varchar & 50 & Kode barang \\
\hline 3 & nm_barang & Varchar & 100 & Nama barang \\
\hline 4 & kategori & Varchar & 100 & $\begin{array}{l}\text { Kategori } \\
\text { barang }\end{array}$ \\
\hline 5 & jenis_barang & Varchar & 100 & Jenis barang \\
\hline 6 & satuan_barang & Varchar & 50 & satuan barang \\
\hline 7 & hrg_barang & Double & 255 & Harga barang \\
\hline 8 & diskon & Int & 11 & Diskon \\
\hline 9 & stk_barang & Int & 11 & stok barang \\
\hline 10 & hit_pesan & Int & 10 & $\begin{array}{l}\text { Hitung } \\
\text { Pesanan }\end{array}$ \\
\hline 11 & gambar & Varchar & 100 & $\begin{array}{l}\text { Gambar } \\
\text { barang }\end{array}$ \\
\hline 12 & keterangan & Text & - & Keterangan \\
\hline 13 & kd_supplier & Varchar & 50 & $\begin{array}{l}\text { Kode } \\
\text { Supplier }\end{array}$ \\
\hline
\end{tabular}

Tabel 3 Data Buku Tamu

Kamus Data dari Data Buku Tamu

\begin{tabular}{lc|l} 
Nama arus data & $:$ & Data Buku Tamu \\
Alias & $:$ & Tamu \\
Bentuk data & $:$ & Formulir \\
Penjelasan & $:$ & Data pengunjung lama maupun baru \\
Periode & & Setiap ada penambahan pengunjung \\
Struktur Data & & baru \\
\hline
\end{tabular}

\begin{tabular}{|c|c|c|c|c|}
\hline No & $\begin{array}{c}\text { Field } \\
\text { Nama }\end{array}$ & Type & Size & Description \\
\hline 1 & id & Int & 10 & Id tabel \\
\hline 2 & $\operatorname{tg} 1$ & Date & - & Tanggal \\
\hline 3 & name & Varchar & 100 & Nama tamu \\
\hline 4 & email & Varchar & 100 & $\begin{array}{l}\text { Alamat email } \\
\text { tamu }\end{array}$ \\
\hline 5 & address & Varchar & 100 & $\begin{array}{l}\text { Alamat tempat } \\
\text { tinggal }\end{array}$ \\
\hline 6 & Isi & text & - & Isi Buku Tamu \\
\hline
\end{tabular}

Tabel 4 Data Konfirmasi

\begin{tabular}{|c|c|c|c|c|}
\hline \multicolumn{5}{|c|}{ Kamus Data dari Data Konfirmasi } \\
\hline \multirow{6}{*}{\multicolumn{2}{|c|}{$\begin{array}{l}\text { Nama arus data } \\
\text { Alias } \\
\text { Bentuk data } \\
\text { Penjelasan } \\
\text { Periode } \\
\text { Struktur Data }\end{array}$}} & \multirow{6}{*}{\multicolumn{3}{|c|}{$\begin{array}{l}\text { Data Konfirmasi } \\
\text { Konfirmasi Transaksi } \\
\text { Dokumen File } \\
\text { Data Konfirmasi transaksi lama } \\
\text { maupun baru } \\
\text { Setiap ada transaksi baru }\end{array}$}} \\
\hline & & & & \\
\hline & & & & \\
\hline & & & & \\
\hline & & & & \\
\hline & & & & \\
\hline No & Field Nama & Type & Size & Description \\
\hline 1 & id_confir & Int & 10 & Id tabel \\
\hline 2 & Nama & Varchar & 200 & $\begin{array}{l}\text { Atas Nama } \\
\text { Pengirim }\end{array}$ \\
\hline 3 & user_id & Varchar & 200 & Id Pengguna \\
\hline 4 & rek_pengirim & Varchar & 255 & $\begin{array}{l}\text { No. Rekening } \\
\text { Pengirim }\end{array}$ \\
\hline 5 & rek_tujuan & Varchar & 255 & $\begin{array}{l}\text { Tujuan } \\
\text { pengiriman }\end{array}$ \\
\hline 6 & tgl_conf & Date & - & $\begin{array}{l}\text { Tanggal } \\
\text { Konfirmasi }\end{array}$ \\
\hline
\end{tabular}

Tabel 5 Data Counter

\begin{tabular}{|c|c|c|c|c|c|}
\hline \multicolumn{6}{|c|}{ Kamus Data dari Data Counter } \\
\hline \multirow{5}{*}{\multicolumn{2}{|c|}{$\begin{array}{l}\text { Nama arus data } \\
\text { Bentuk data } \\
\text { Penjelasan } \\
\text { Periode } \\
\text { Struktur Data }\end{array}$}} &. & \multicolumn{3}{|c|}{ Data Counter } \\
\hline & & : & \multicolumn{3}{|c|}{ Dokumen File } \\
\hline & & : & \multirow{2}{*}{\multicolumn{3}{|c|}{$\begin{array}{l}\text { Data counter lama maupun baru } \\
\text { Setiap ada penambahan counter baru }\end{array}$}} \\
\hline & & : & & & \\
\hline & & & & & \\
\hline No & Field & & Type & Size & Description \\
\hline 1 & Id_cou & & Int & 11 & Id tabel \\
\hline
\end{tabular}

Tabel 6 Data Pesanan Barang

\begin{tabular}{|c|c|c|c|c|}
\hline \multicolumn{5}{|c|}{ Kamus Data dari Data Pesanan Barang } \\
\hline \multicolumn{2}{|c|}{$\begin{array}{l}\text { Nama arus } \\
\text { data } \\
\text { Bentuk data } \\
\text { Penjelasan } \\
\text { Periode } \\
\text { Struktur Data }\end{array}$} & \multicolumn{3}{|c|}{$\begin{array}{l}\text { Data Pesanan Barang } \\
\text { Dokumen File } \\
\text { Data Pesanan lama maupun baru } \\
\text { Setiap Pesanan baru }\end{array}$} \\
\hline No & Field Nama & Type & $\begin{array}{l}\text { Si } \\
\text { ze }\end{array}$ & Description \\
\hline 1 & kd_pesan & Int & 11 & Id Tabel \\
\hline 2 & kd_barang & $\begin{array}{l}\text { Varc } \\
\text { har }\end{array}$ & 50 & Id Barang pesanan \\
\hline 3 & user & $\begin{array}{l}\text { Varc } \\
\text { har }\end{array}$ & 50 & Nama Pemesan \\
\hline 4 & $\begin{array}{l}\text { nm_barangp } \\
\text { sn }\end{array}$ & $\begin{array}{l}\text { Varc } \\
\text { har }\end{array}$ & $\begin{array}{c}25 \\
5 \\
\end{array}$ & Nama barang pesanan \\
\hline 5 & $\begin{array}{l}\text { hrg_barangp } \\
\text { sn }\end{array}$ & $\begin{array}{c}\text { Doub } \\
\text { le }\end{array}$ & - & Harga barang pesanan \\
\hline 6 & jml_pesan & Int & 11 & Jumlah pesanan \\
\hline 7 & tot_harga & $\begin{array}{c}\text { Doub } \\
\text { le }\end{array}$ & - & Total Harga \\
\hline 8 & tgl_pesan & Date & - & Tanggal pesan \\
\hline 9 & mau_pesan & $\begin{array}{c}\text { Enu } \\
\mathrm{m}\end{array}$ & - & $\begin{array}{l}\text { Keterangan } \\
\text { pemesanan }\end{array}$ \\
\hline
\end{tabular}




\begin{tabular}{|c|l|c|c|l|}
\hline 10 & nm_bank & $\begin{array}{c}\text { Varc } \\
\text { har }\end{array}$ & $\begin{array}{c}20 \\
0\end{array}$ & Nama Bank Pesanan \\
\hline
\end{tabular}

Tabel 7 Data Return

\begin{tabular}{|c|c|c|c|c|}
\hline \multicolumn{5}{|c|}{ Kamus Data dari Data Return } \\
\hline \multicolumn{2}{|c|}{$\begin{array}{l}\text { Nama arus data } \\
\text { Alias } \\
\text { Bentuk data } \\
\text { Penjelasan } \\
\text { Periode } \\
\text { Struktur Data }\end{array}$} & \multicolumn{3}{|c|}{$\begin{array}{l}\text { Data Return } \\
\text { Return Barang } \\
\text { Dokumen Dasar } \\
\text { Data Return lama maupun baru } \\
\text { Setiap ada penambahan return } \\
\text { baru }\end{array}$} \\
\hline No & Field Nam: & Type & Size & Description \\
\hline 1 & id_return & Int & 11 & Id tabel \\
\hline 2 & tgl_beli & Date & - & $\begin{array}{l}\text { Tanggal } \\
\text { pembelian }\end{array}$ \\
\hline 3 & nama_barang & Varchar & 255 & Nama Barang \\
\hline 4 & kd_supplier & Varchar & 100 & Id Supplier \\
\hline 5 & jml_barang & Int & 11 & $\begin{array}{l}\text { Jumlah } \\
\text { Barang yg } \\
\text { diReturn } \\
\end{array}$ \\
\hline 6 & ket & Text & - & Keterangan \\
\hline
\end{tabular}

Tabel 8 Data Supplier

\begin{tabular}{|c|c|c|c|c|}
\hline \multicolumn{5}{|c|}{ Kamus Data dari Data Supplier } \\
\hline \multicolumn{2}{|c|}{$\begin{array}{l}\text { Nama arus data } \\
\text { Bentuk data } \\
\text { Penjelasan } \\
\text { Periode } \\
\text { Struktur Data }\end{array}$} & \multicolumn{3}{|c|}{$\begin{array}{l}\text { Data Supplier } \\
\text { Formulir } \\
\text { Data supplier lama maupun baru } \\
\text { Setiap ada penambahan supplier } \\
\text { baru }\end{array}$} \\
\hline No & Field Nama & Type & Size & Description \\
\hline 1 & kd_suppl & Varchar & 50 & Id Supplier \\
\hline 2 & nm_suppl & Varchar & 100 & Nama Supplier \\
\hline 3 & almt_suppl & Varchar & 100 & $\begin{array}{l}\text { Alamat } \\
\text { Supplier }\end{array}$ \\
\hline 4 & no_tlp & Varchar & 100 & $\begin{array}{l}\text { No Telepon } \\
\text { supplier }\end{array}$ \\
\hline
\end{tabular}

Tabel 9 Data Pelanggan

\begin{tabular}{|c|c|c|c|c|}
\hline \multicolumn{5}{|c|}{ Kamus Data dari Data Pelanggan } \\
\hline \multicolumn{2}{|c|}{$\begin{array}{l}\text { Nama arus data } \\
\text { Alias } \\
\text { Bentuk data } \\
\text { Penjelasan } \\
\text { Periode } \\
\text { Struktur Data }\end{array}$} & \multicolumn{3}{|c|}{$\begin{array}{l}\text { Data Pelanggan } \\
\text { Member } \\
\text { Formulir } \\
\text { Data pelanggan lama maupun } \\
\text { baru } \\
\text { Setiap ada penambahan } \\
\text { pelanggan baru }\end{array}$} \\
\hline No & Field Nama & Type & Size & Description \\
\hline 1 & User_ID & varchar & 50 & Id tabel \\
\hline 2 & Password & varchar & 100 & Password \\
\hline 3 & Sesion & varchar & 100 & Session \\
\hline 4 & $\begin{array}{l}\text { Nama_Lengka } \\
\text { p }\end{array}$ & varchar & 100 & $\begin{array}{l}\text { Nama } \\
\text { Pelanggan }\end{array}$ \\
\hline 5 & Email & varchar & 100 & Email \\
\hline 6 & Fax & varchar & 255 & Fax \\
\hline 7 & Tg1_Daftar & date & - & $\begin{array}{l}\text { Tanggal } \\
\text { daftar }\end{array}$ \\
\hline 8 & No_Hp & varchar & 50 & $\begin{array}{l}\text { Nomor } \\
\text { Handphone }\end{array}$ \\
\hline 9 & No_Tlp & varchar & 50 & $\begin{array}{l}\text { Nomor } \\
\text { telepon }\end{array}$ \\
\hline 10 & $\begin{array}{l}\text { Alamat_Lengk } \\
\text { ap }\end{array}$ & varchar & 100 & $\begin{array}{l}\text { Alamat } \\
\text { tempat } \\
\text { tinggal }\end{array}$ \\
\hline 11 & $\begin{array}{l}\text { Alamat_Altern } \\
\text { atif }\end{array}$ & varchar & 100 & $\begin{array}{l}\text { Alamat } \\
\text { kedua }\end{array}$ \\
\hline
\end{tabular}

\section{Rancangan Output dan Input Rancangan Output}

Berikut ini tampilan interface website dimana dapat di akses link dengan Admin, Lihat Katalog Produk, Lihat Profil\&kontak Perusahaan.

\section{Index Home}

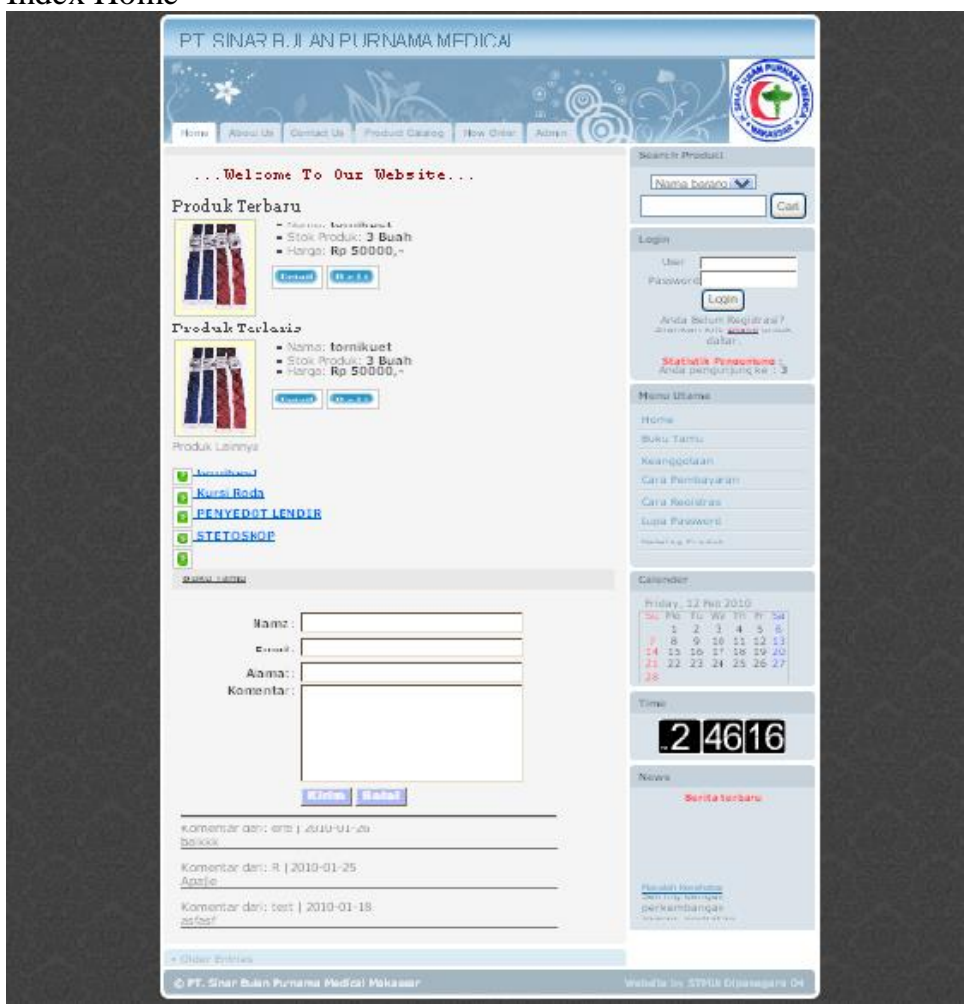

\section{Gambar 9 Index Home}

Menu Buku Tamu

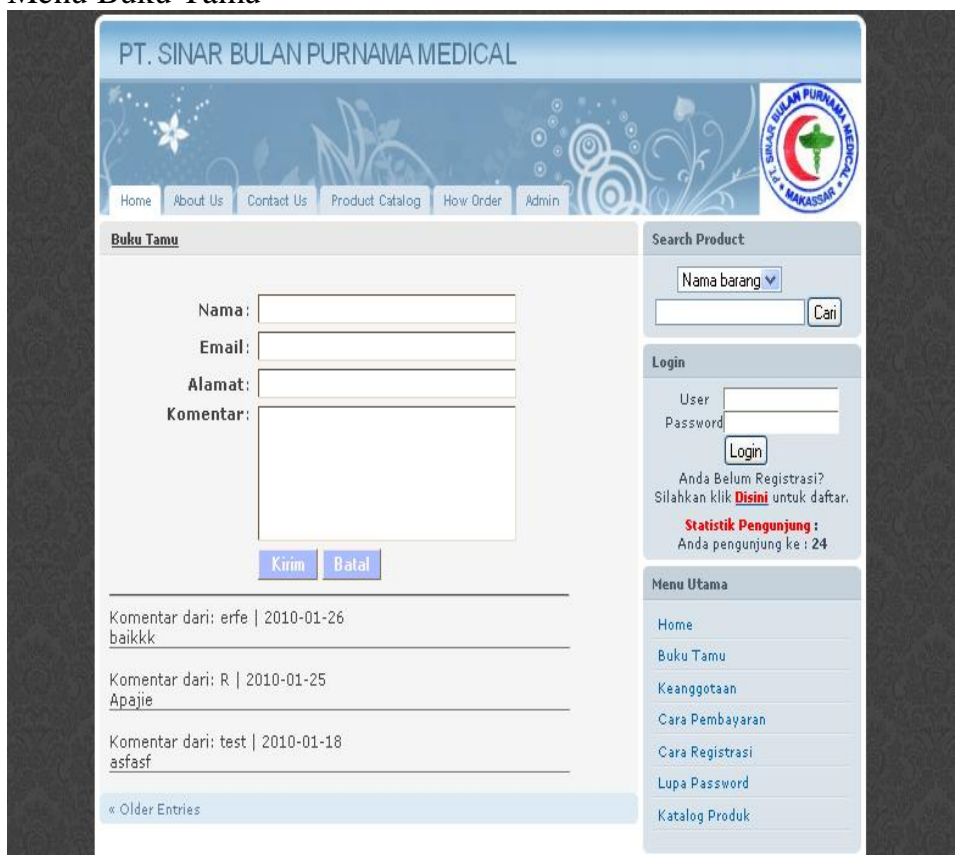

Gambar 10 Menu Buku Tamu 
Menu Keanggotaan

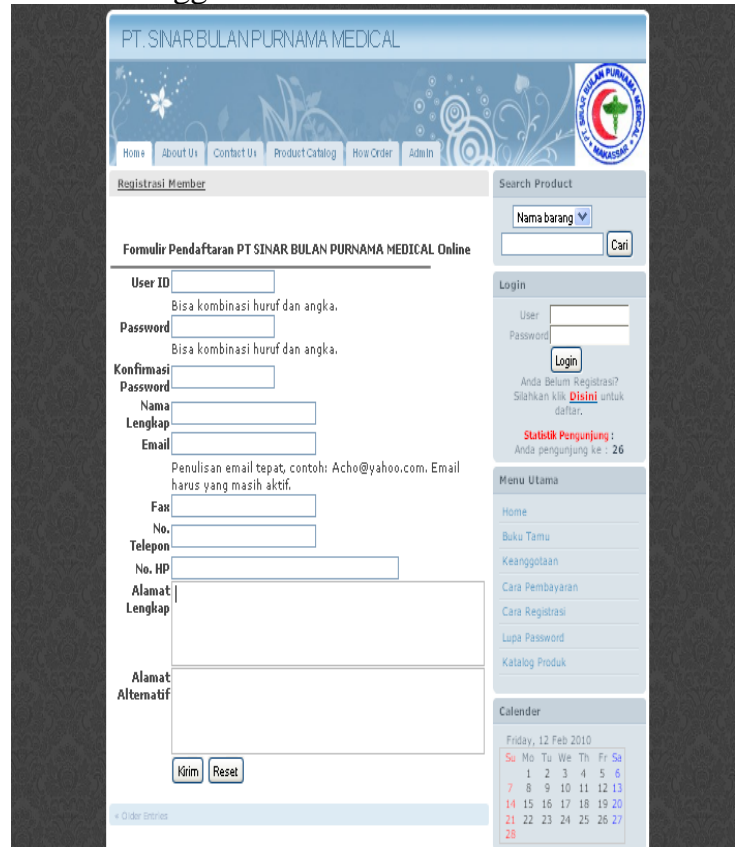

Gambar 11 Menu Keanggotaan

Menu Katalog Produk

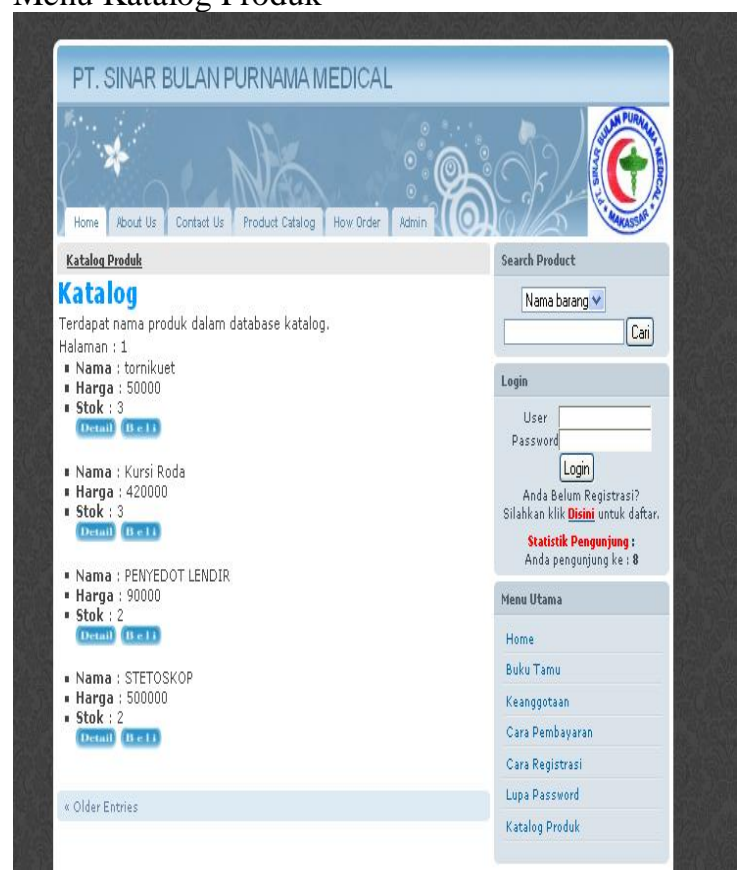

Gambar 12 Menu Katalog Produk
Admin

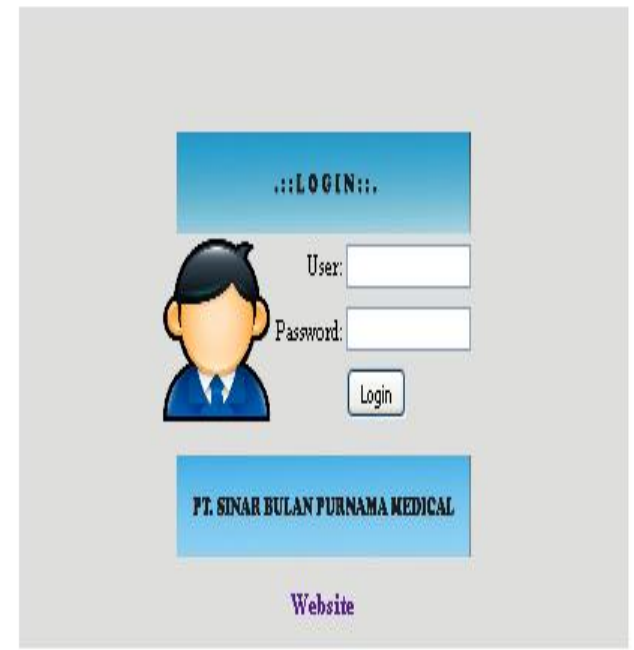

Gambar 13 Admin

Index Admin

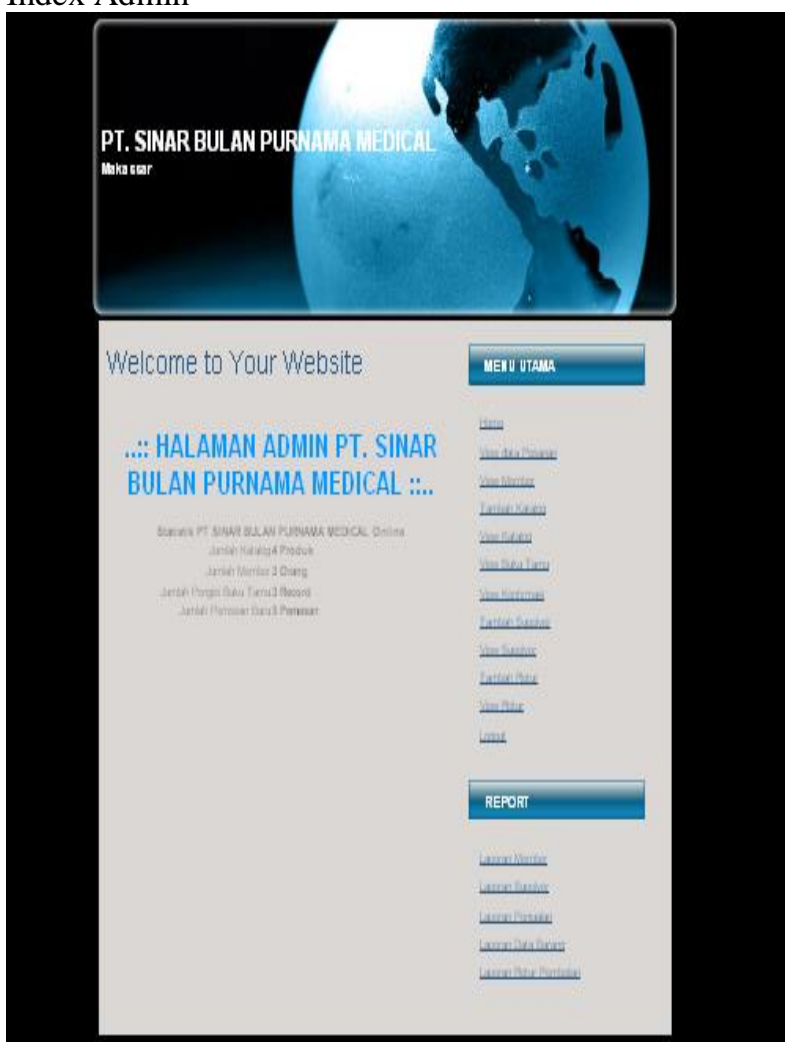

Gambar 14 Index Admin 
Menu View Member

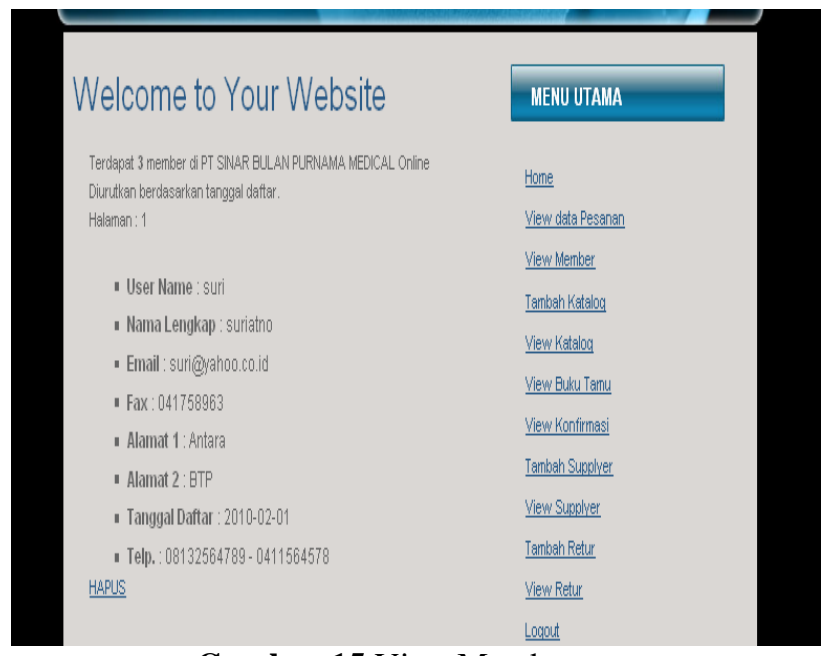

Gambar 15 View Member

Menu View Supplier

\begin{tabular}{|c|c|}
\hline Welcome to Your Website & MENUUTAMA \\
\hline & Hone \\
\hline Terdapat 3 nana Supplyer dalan ditabase. & View data Pesanan \\
\hline \multirow[t]{2}{*}{ Halannan:1 } & View Mennber \\
\hline & Tannah Kataloy \\
\hline - Kode Supplyer : 8002 & View Katallog \\
\hline - Nama Supplyer : PT. Latitim & View Buku Tanu \\
\hline - Alamat Supplyer : Jn. Cendawasih & View Konfinasi \\
\hline - No. Telp :0411234510 & Tanbah Supplver \\
\hline \multirow[t]{2}{*}{ EDITHAPUS } & View Supplver \\
\hline & Tanbah Retur \\
\hline - Kode Supplyer : 5004 & View Retur \\
\hline - Nama Supplyer : PT. Kimia & Logoout \\
\hline - Alamat Supplyer : Jl. Sam Ratulangi & \\
\hline $\begin{array}{l}\text { 'No. Ielp?:02159846363 } \\
\text { ENIHAPS }\end{array}$ & REPORT \\
\hline
\end{tabular}

Gambar 16 View Supplier

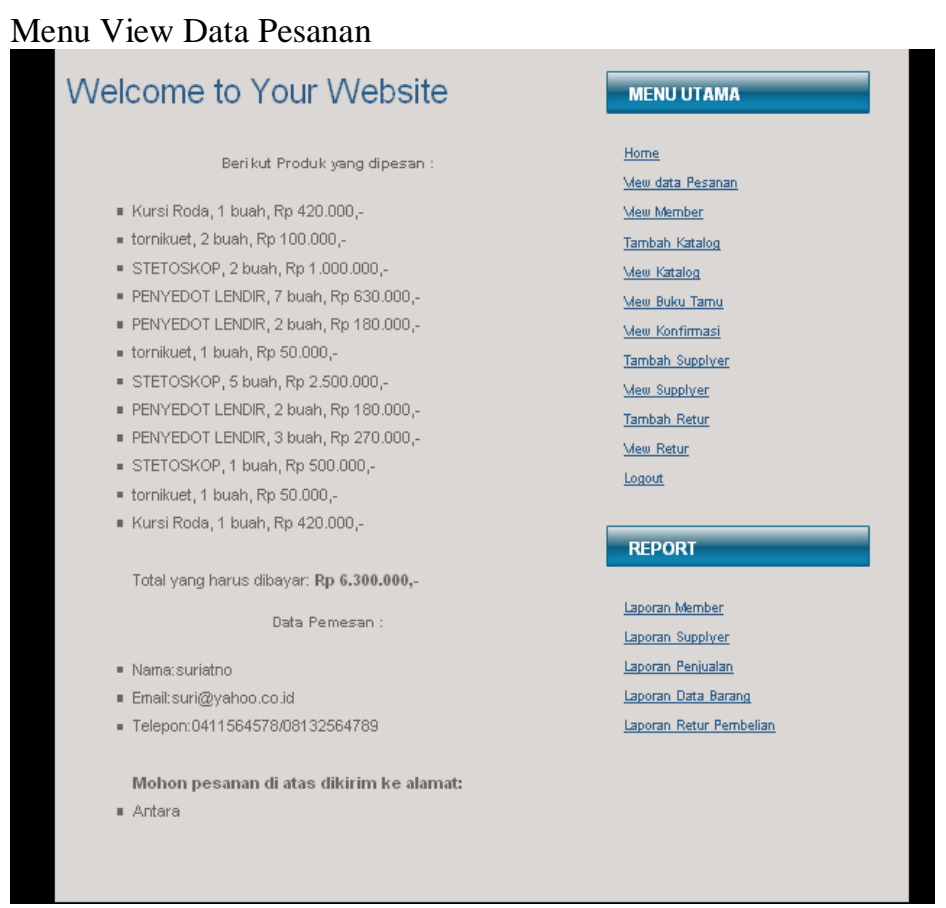

Gambar 17 View Data Pesanan

Menu View Konfirmasi

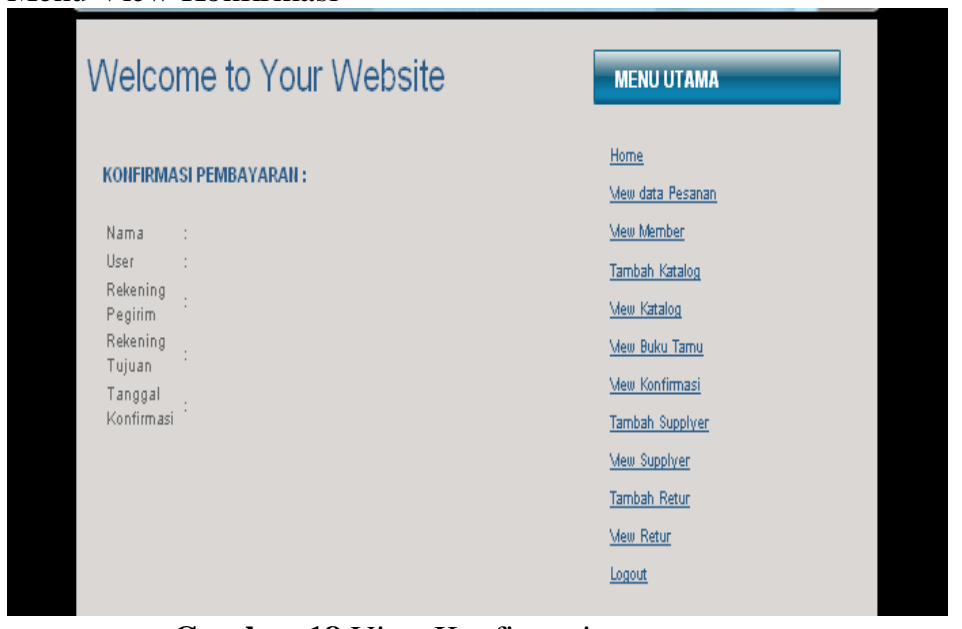

Gambar 18 View Konfirmasi 


\section{Rancangan Input}

Berikut ini tampilan interface website dimana dapat di akses link tambah katalog buku,

Menu Tambah Katalog Produk

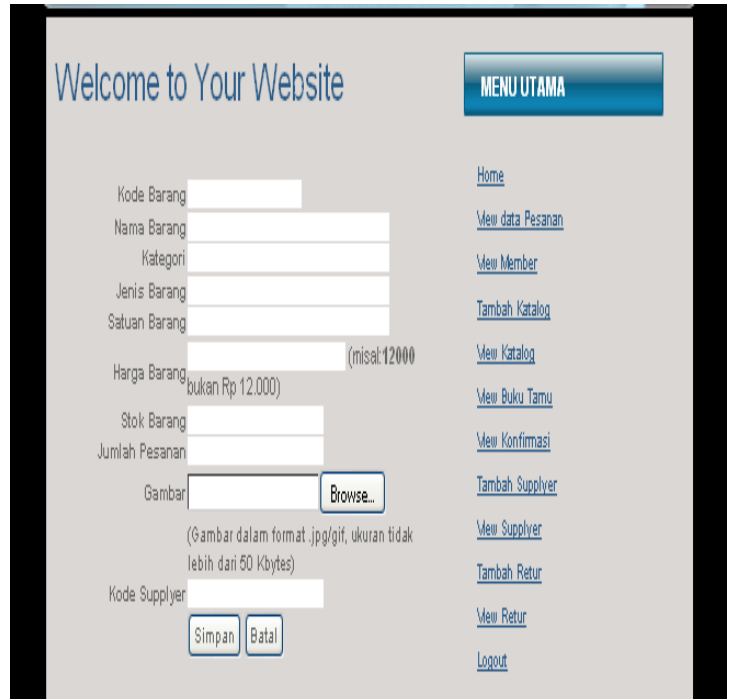

Gambar 19 Tambah Katalog Produk

Menu Input Supplier

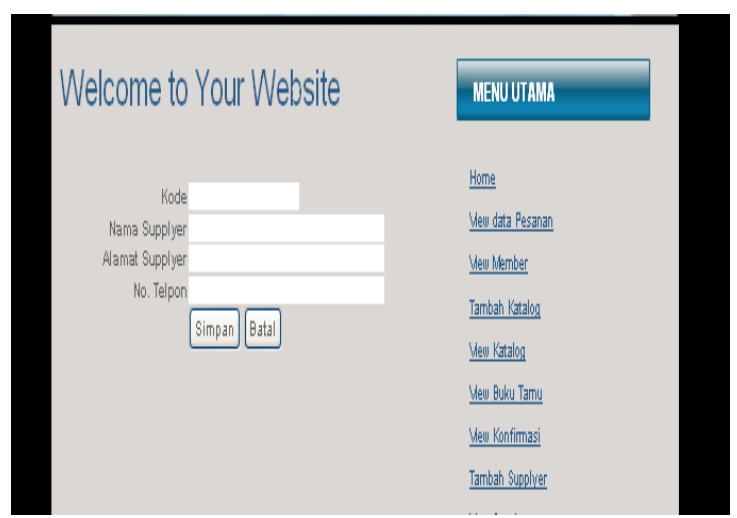

Gambar 20 Menu Input Berita
Menu Input Return Beli

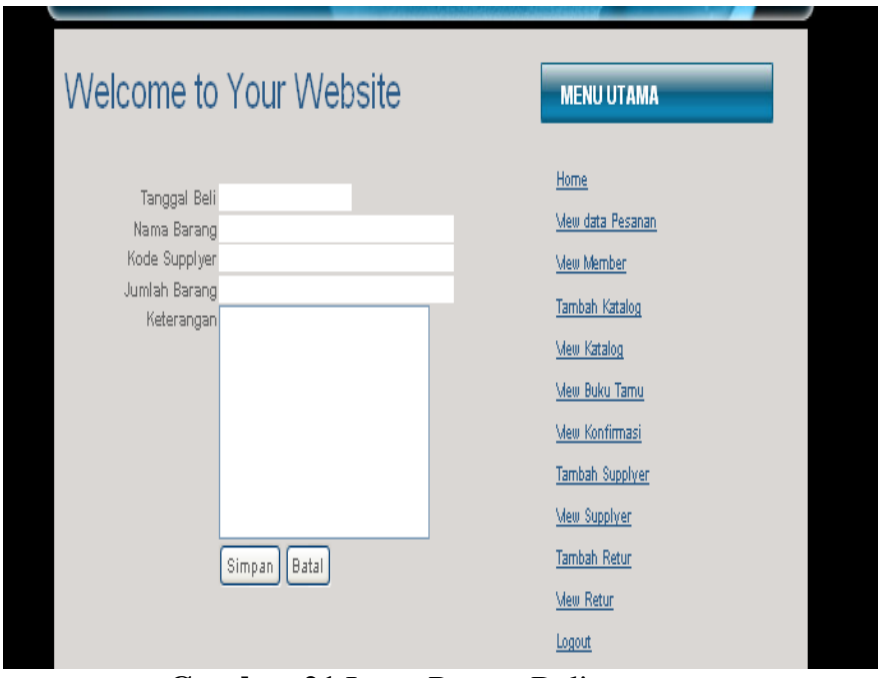

Gambar 21 Input Return Beli

\section{Rancangan Data Base Relasi Tabel}

7 o theld supplyer Okd_suppl : varchar(50) (1) nm_supp : varchar $(100)$

(1) almt supp : varchar $(100)$

90 no_tlp : varchar(100)

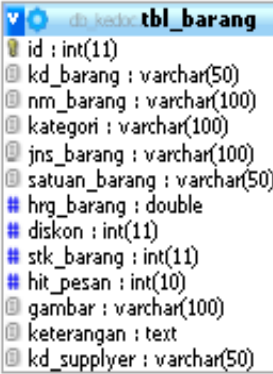

\begin{tabular}{|c|}
\hline \\
\hline 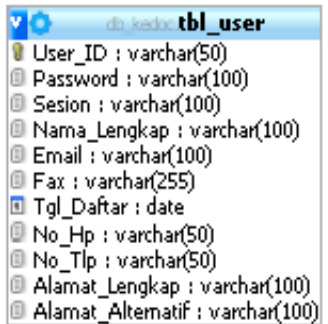 \\
\hline
\end{tabular}

\section{0 da kedal_pesanan}

8 kd pesan : int(11)

(1) kd barang : varchar(50)

(1) user : varchar $(50)$

(10 nm_barangpsn : varchar(255)

\# hrg_barangpsn : double

\# jmilpesan : int(11)

\# tot harga : double

0 tol pesan : date

Q mau pesan : enum( $(0$ ', ' 1 ')

(1) nm_bank : warchar $(200)$

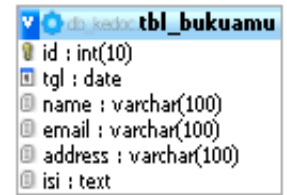

$\nabla$ (o) thetur 8 id_retur : int(11) I. tgi beli : date

(1) nama_barang : varchar(255)

(1) kd supplyer: warchar $(100)$

\# jmi_barang : int(11)

(1) ket : text

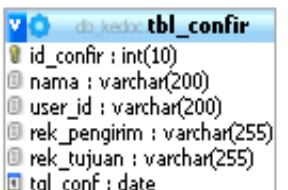

[ tgl_conf : date

V0 do kado tbl_counter $\#$ id cout : int(11)

Gambar 22 Relasi Tabel 


\section{Struktur Tabel}

Tabel 10 Struktur Tabel Admin

1. Nama Tabel = tbl_admin

2. Media $=$ Hardisk

3. Field Kunci $=$ id

4. Fungsi $=$ Penyimpanan Data Admin

\begin{tabular}{|c|l|c|c|l|}
\hline No. & Nama Item & Type & Lebar & Keterangan \\
\hline 1 & id & Int & 4 & Id tabel \\
\hline 2 & user & varchar & 10 & Nama user \\
\hline 3 & pass & varchar & 100 & Password \\
\hline 4 & sesi & varchar & 100 & Session \\
\hline 5 & aktif & enum & - & Status keaktifan \\
\hline 6 & nama & varchar & 100 & Nama Admin \\
\hline 7 & email & varchar & 90 & Email Admin \\
\hline
\end{tabular}

Tabel 11 Struktur Tabel Barang

1. Nama Tabel = tbl_barang

2. Media $=$ Hardisk

3. Field Kunci $=$ id

4. Fungsi $=$ Penyimpanan Data Katalog

Produk

\begin{tabular}{|c|l|c|c|l|}
\hline No. & Nama Item & Type & Lebar & Keterangan \\
\hline 1 & Id & Int & 11 & Id tabel \\
\hline 2 & kd_barang & Varchar & 50 & Kode barang \\
\hline 3 & nm_barang & varchar & 100 & Nama barang \\
\hline 4 & kategori & varchar & 100 & $\begin{array}{l}\text { Kategori } \\
\text { barang }\end{array}$ \\
\hline 5 & jenis_barang & varchar & 100 & Jenis barang \\
\hline 6 & satuan_barang & varchar & 50 & satuan barang \\
\hline 7 & hrg_barang & double & 255 & Harga barang \\
\hline 8 & Diskon & int & 11 & Diskon \\
\hline 9 & stk_barang & int & 11 & stok barang \\
\hline 10 & hit_pesan & int & 10 & $\begin{array}{l}\text { Hitung } \\
\text { Pesanan }\end{array}$ \\
\hline 11 & gambar & varchar & 100 & $\begin{array}{l}\text { Gambar } \\
\text { barang }\end{array}$ \\
\hline 12 & keterangan & text & - & Keterangan \\
\hline 13 & kd_supplier & varchar & 50 & $\begin{array}{l}\text { Kode } \\
\text { Supplier }\end{array}$ \\
\hline
\end{tabular}

Tabel 12 Struktur Tabel Buku Tamu

1. Nama Tabel = tbl_bukuamu

2. Media $=$ Hardisk

3. Field Kunci $=$ id

4. Fungsi $=$ Penyimpanan Data Buku

Tamu

\begin{tabular}{|c|l|c|c|l|}
\hline No. & Nama Item & Type & Lebar & Keterangan \\
\hline 1 & Id & int & 10 & Id tabel \\
\hline 2 & Tgl & date & - & Tanggal \\
\hline 3 & Name & varchar & 100 & Nama tamu \\
\hline 4 & Email & varchar & 100 & $\begin{array}{l}\text { Alamat email } \\
\text { tamu }\end{array}$ \\
\hline 5 & Address & varchar & 100 & $\begin{array}{l}\text { Alamat tempat } \\
\text { tinggal }\end{array}$ \\
\hline 6 & Isi & text & - & Isi Buku Tamu \\
\hline
\end{tabular}

Tabel 13 Struktur Tabel Konfirmasi

1. Nama Tabel = tbl_confir

2. Media $=$ Hardisk

3. Field Kunci = id_confir

4. Fungsi = Penyimpanan Data

Konfirmasi Transaksi

\begin{tabular}{|c|l|c|c|l|}
\hline No. & Nama Item & Type & Lebar & \multicolumn{1}{|c|}{ Keterangan } \\
\hline 1 & id_confir & Int & 10 & Id tabel \\
\hline 2 & nama & varchar & 200 & Atas Nama Pengirim \\
\hline 3 & user_id & varchar & 200 & Id Pengguna \\
\hline 4 & rek_pengirim & varchar & 255 & No. Rekening Pengirim \\
\hline 5 & rek_tujuan & varchar & 255 & Tujuan pengiriman \\
\hline 6 & tgl_conf & date & - & Tanggal Konfirmasi \\
\hline
\end{tabular}

Tabel 14 Struktur Tabel Counter

1. Nama Tabel = tbl_counter

2. Media $=$ Hardisk

3. Field Kunci $=$ id_cout

4. Fungsi $=$ Penyimpanan Data Counter

\begin{tabular}{|c|c|c|c|l|}
\hline No. & $\begin{array}{c}\text { Nama } \\
\text { Item }\end{array}$ & Type & Lebar & Keterangan \\
\hline 1 & Id_cout & Int & 11 & Id tabel \\
\hline
\end{tabular}

Tabel 15 Struktur Tabel Pesanan Barang

1. Nama Tabel = tbl_pesans

2. Media $=$ Hardisk

3. Field Kunci $=$ kd_pesan

4. Fungsi = Penyimpanan Data Pesanan

Barang

\begin{tabular}{|c|l|c|c|l|}
\hline No. & Nama Item & Type & Lebar & \multicolumn{1}{|c|}{ Keterangan } \\
\hline 1 & kd_pesan & Int & 11 & Id Tabel \\
\hline 2 & kd_barang & varchar & 50 & Id Barang pesanan \\
\hline 3 & User & varchar & 50 & Nama Pemesan \\
\hline 4 & nm_barangpsn & varchar & 255 & Nama barang pesanan \\
\hline 5 & hrg_barangpsn & double & - & Harga barang pesanan \\
\hline 6 & jml_pesan & int & 11 & Jumlah pesanan \\
\hline 7 & tot_harga & double & - & Total Harga \\
\hline 8 & tgl_pesan & date & - & Tanggal pesan \\
\hline 9 & mau_pesan & enum & - & Keterangan pemesanan \\
\hline 10 & nm_bank & varchar & 200 & Nama Bank Pesanan \\
\hline
\end{tabular}

Tabel 16 Struktur Tabel Return

1. Nama Tabel = tbl_retur

2. Media $=$ Hardisk

3. Field Kunci = id_return

4. Fungsi = Penyimpanan Data Return barang

\begin{tabular}{|c|l|c|c|l|}
\hline No. & Nama Item & Type & Lebar & \multicolumn{1}{|c|}{ Keterangan } \\
\hline 1 & id_return & Int & 11 & Id tabel \\
\hline 2 & tgl_beli & date & - & Tanggal pembelian \\
\hline 3 & nama_barang & varchar & 255 & Nama Barang \\
\hline 4 & kd_supplier & varchar & 100 & Id Supplier \\
\hline 5 & jml_barang & Int & 11 & Jumlah Barang yg diReturn \\
\hline 6 & Ket & text & - & Keterangan \\
\hline
\end{tabular}


Tabel 17 Struktur Tabel Supplier

1. Nama Tabel = tbl_supplyer

2. Media = Hardisk

3. Field Kunci $=$ kd_suppl

4. Fungsi $=$ Penyimpanan Data Supplier

\begin{tabular}{|c|l|c|c|l|}
\hline No. & Nama Item & Type & Lebar & Keterangan \\
\hline 1 & kd_suppl & varchar & 50 & Id Supplier \\
\hline 2 & nm_suppl & varchar & 100 & Nama Supplier \\
\hline 3 & almt_suppl & varchar & 100 & Alamat Supplier \\
\hline 4 & no_tlp & varchar & 100 & $\begin{array}{l}\text { No Telepon } \\
\text { supplier }\end{array}$ \\
\hline
\end{tabular}

Tabel 18 Struktur Tabel Member

1. Nama Tabel = tbl_user

2. Media $=$ Hardisk

3. Field Kunci $=$ User_ID

4. Fungsi $=$ Penyimpanan Data Member

\begin{tabular}{|c|l|c|c|l|}
\hline No. & \multicolumn{1}{|c|}{ Nama Item } & Type & Lebar & Keterangan \\
\hline 1 & User_ID & varchar & 50 & Id tabel \\
\hline 2 & Password & varchar & 100 & Password \\
\hline 3 & Sesion & varchar & 100 & Session \\
\hline 4 & Nama_Lengkap & varchar & 100 & $\begin{array}{l}\text { Nama } \\
\text { Pelanggan }\end{array}$ \\
\hline 5 & Email & varchar & 100 & Email \\
\hline 6 & Fax & varchar & 255 & Fax \\
\hline 7 & Tgl_Daftar & Date & - & $\begin{array}{l}\text { Tanggal } \\
\text { daftar }\end{array}$ \\
\hline 8 & No_Hp & varchar & 50 & $\begin{array}{l}\text { Nomor } \\
\text { Handphone }\end{array}$ \\
\hline 9 & No_Tlp & varchar & 50 & $\begin{array}{l}\text { Nomor } \\
\text { telepon }\end{array}$ \\
\hline 10 & Alamat_Lengkap & varchar & 100 & $\begin{array}{l}\text { Alamat } \\
\text { tempat } \\
\text { tinggal }\end{array}$ \\
\hline 11 & Alamat_Alternatif & varchar & 100 & $\begin{array}{l}\text { Alamat } \\
\text { kedua }\end{array}$ \\
\hline
\end{tabular}

\section{PENGUJIAN SISTEM}

Tahap Pengujian Sistem

Pengujian White Box

Flowgraph Menu Utama

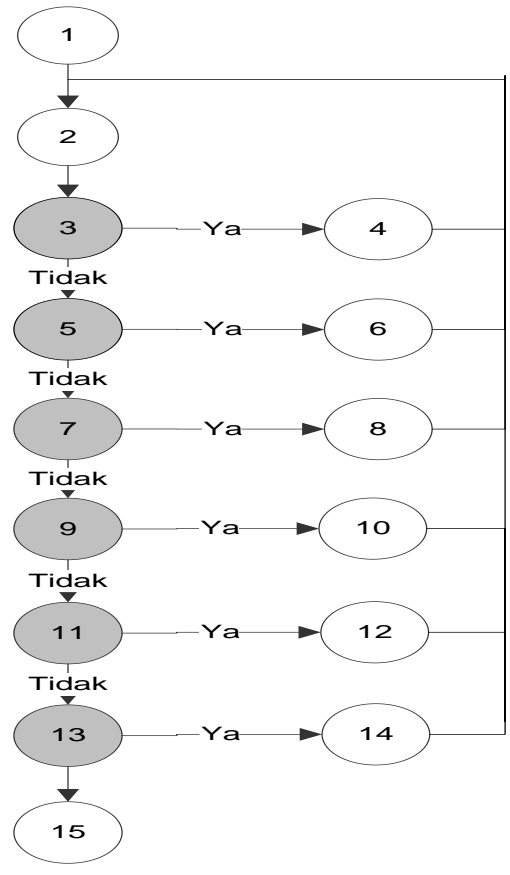

Gambar 23. Flowgraph Menu Utama

\section{Flowgraph Home}

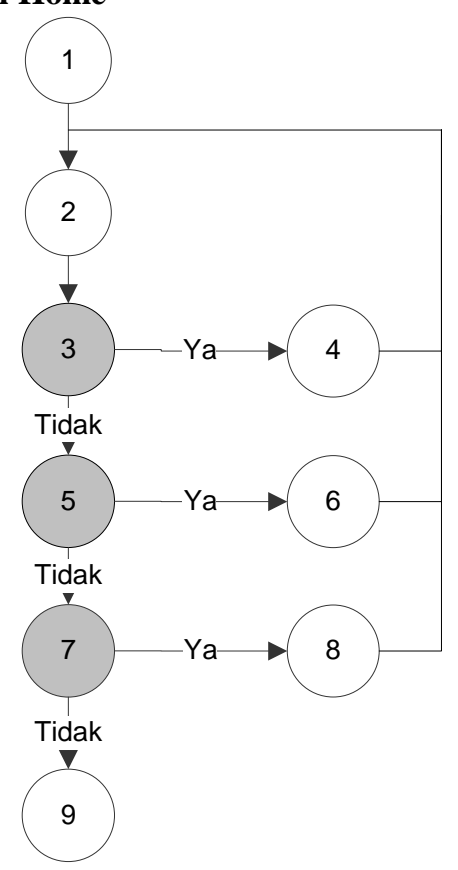

Gambar 24. Flowgraph Home 


\section{Flowgraph Buku Tamu}

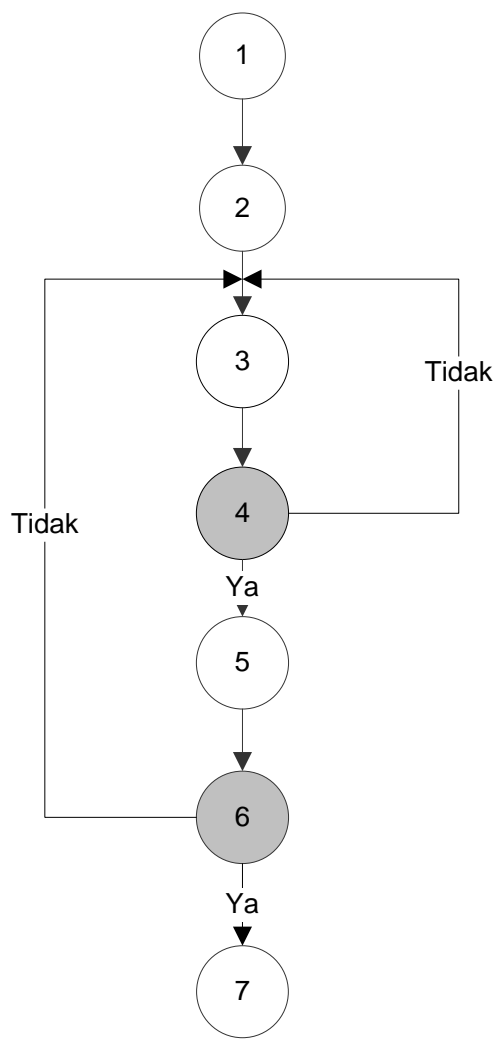

Gambar 25. Flowgraph Buku Tamu

\section{Flowgraph Keanggotaan}

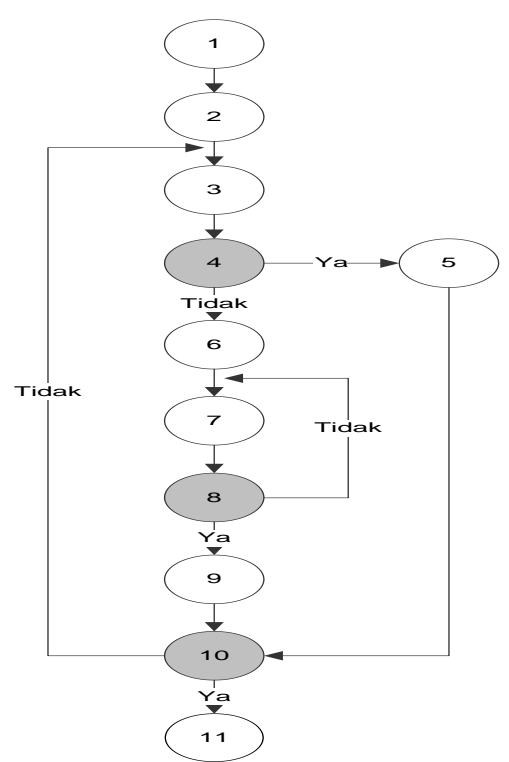

Gambar 26. Flowgraph Buku Tamu

\section{Flowgraph Katalog Produk}

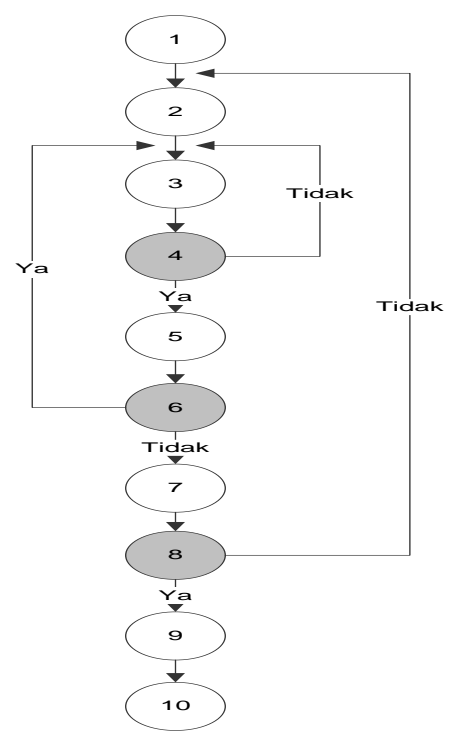

Gambar 27 Flowgraph Katalog Produk

Flowgraph Admin

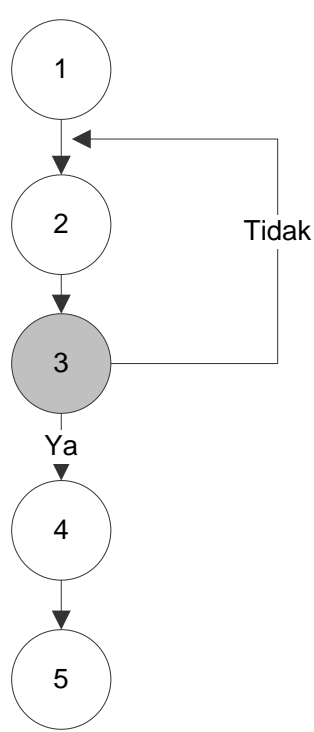

Gambar 28. Flowgraph Admin 


\section{Flowgraph Menu Admin}

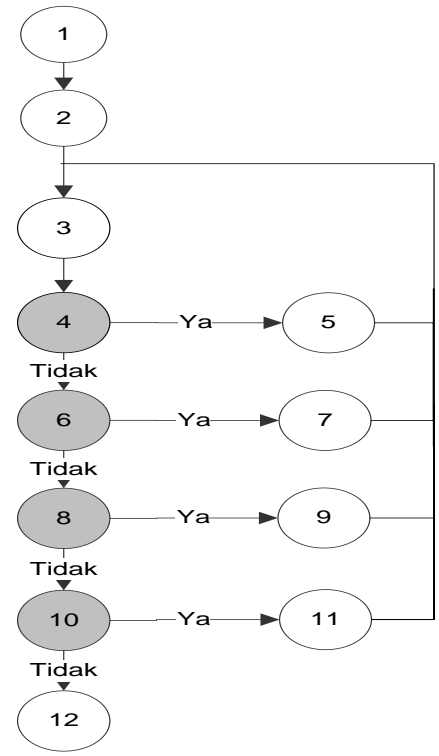

Gambar 29 Flowgraph Menu Admin

\section{Flowgraph Input Data}

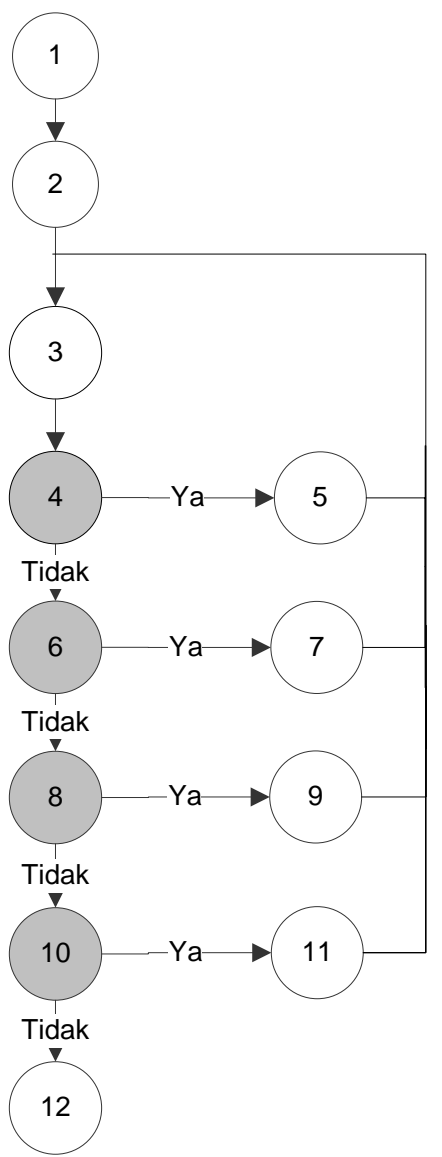

Gambar 30 Flowgraph Input Data

\section{Flowgraph Report}

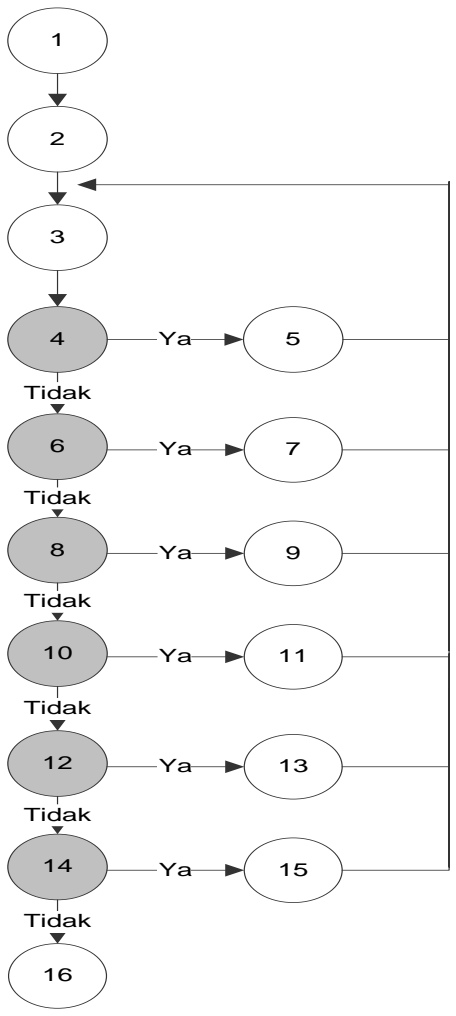

Gambar 31 Flowgraph Report

\section{Flowgraph Logout}

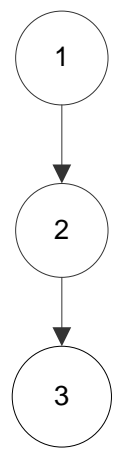

Gambar 32 Flowgraph Logout 


\section{Hasil Pengujian White Box}

Berikut ini adalah hasil dari setiap pengujian sistem yang telah di uji dengan menggunakan pengujian White Box pada tabel di bawah ini :

Tabel 5.1 Hasil Pengujian White Box

\begin{tabular}{|l|l|l|l|l|}
\hline No & Flowgraph & $\begin{array}{l}\text { Independen } \\
\text { Path }\end{array}$ & Region & $\begin{array}{l}\text { Komple } \\
\text { sitas } \\
\text { Sikloma } \\
\text { tis }\end{array}$ \\
\hline 1 & Menu Utama & 7 & 7 & 7 \\
\hline 2 & Home & 4 & 4 & 4 \\
\hline 3 & Buku Tamu & 3 & 3 & 3 \\
\hline 4 & Keanggotaan & 4 & 4 & 4 \\
\hline 5 & Katalog Produk & 4 & 4 & 4 \\
\hline 6 & Admin & 2 & 2 & 2 \\
\hline 7 & Menu Admin & 5 & 5 & 5 \\
\hline 8 & Input Data & 5 & 5 & 5 \\
\hline 9 & Report & 7 & 7 & 7 \\
\hline 10 & Log Out & 1 & 1 & 1 \\
\hline
\end{tabular}

Dari hasil pengujian perangkat lunak di atas dapat ditarik kesimpulan bahwa dalam pengujian tersebut tidak terjadi kesalahan baik logika maupun program, karena tidak ditemukan suatu perhitungan logika dalam hal ini pengujian sistem menggunakan White Box yg berbeda.

\section{KESIMPULAN}

Tujuan dari desain perancangan sistem informasi berbasis web ini adalah untuk memaksimalkan sistem penjualan dan pemasaran alat kesehatan dan kedokteran pada PT. Sinar Bulan Purnama Medical Makassar dan untuk mempermudah konsumen memperoleh informasi sekaligus memesan produk secara online. Dan dari permasalahan yang telah diuraikan sebelumnya pada BAB I, maka dapat disimpulkan sebagai berikut:

1. Dengan adanya rancangan sistem penjualan dan pemasaran ini dapat membantu pihak PT. Sinar Bulan Purnama Medical Makassar dalam menangani masalah penjualan dan pemasaran yang kurang maksimal dengan membangun sebuah sistem penjualan online berbasis web.

2. Dengan adanya sistem penjualan seperti ini diharapkan akan lebih mempermudah para konsumen dalam memperoleh informasi tentang penjualan produk pada PT. Sinar Bulan Purnama Medical Makassar.

3. Hasil dari pengujian yang telah dilakukan telah membuktikan bahwa program telah bebas dari kesalahan logika.

\section{SARAN}

Dari kesimpulan yang dijabarkan diatas, maka penulis menyampaikan saran-saran yang dapat dijadikan pertimbangan dan masukan. Saran-saran tersebut antara lain.

1. Agar rancangan penjualan dan pemasaran online yang telah dibuat oleh penulis dapat benar-benar meningkatkan perkembangan sistem penjualan pada PT. Sinar Bulan Purnama Medical Makassar tersebut, maka disarankan kepada pihak PT. Sinar Bulan Purnama Medical Makassar agar meng-Up Load rancangan Website ini agar dapat digunakan oleh masyarakat melalui media internet secara online.

2. Dengan adanya sistem penjualan dan pemasaran seperti ini diharapkan agar pihak PT. Sinar Bulan Purnama Medical Makassar dan konsumen dapat menggunakan fasilitas yang telah disediakan dalam website yang penulis buat.

Pada akhirnya penulis mengharapkan agar sistem penjualan online dapat dikembangkan lebih lanjut, sehingga pemahaman tentang website tidak hanya diketahui oleh kalangan IT saja tetapi masyarakat umum juga bisa megaplikasikan website tersebut.

\section{DAFTAR PUSTAKA}

- Abdul Kadir, 2002. "Pengenalan PHP dan MySQL”. Andi Offset, Yogyakarta.

- Abdul Kadir, 2003. "Konsep dan Tuntunan Praktis Basis Data”. Andi Offset, Yogyakarta.

- Baum, David, 1999. "E-Commerce". http://Jakarta.Linux.or.id/artikel.php, "Bussines Links". Oracle Magazine. (akses 20/06/2008)

- Fathansyah, Ir. 2001. “Basis Data”, Informatika, Bandung.

- Jogiyanto, H.M., 1999-2001. “Analisis dan Desain Sistem informasi Pendekatan Terstruktur Teori dan Aplikasi Bisnis". Andi Offset, Yogyakarta.

- Kristanto, Harianto, 1999-1994. "Konsep Dan Perancangan Database”. Andi Offset, Yogyakarta.

- Peranginangin, Kasiman, 2006. "Aplikasi Web dengan PHP dan MySQL". Andi Offset, Yogyakarta.

- Pressman, Roger R, 2002. "Rekayasa Perangkat Lunak Pendekatan Praktisi". Andi Offset, Yogyakarta.

- Janner_pengenalan_ecommerce.pdf (akses $15 / 11 / 2005)$

- Simarmata, Janner . "Pengenalan ECommerce". http://MateriKuliah.Com/

- Sunatrihantono, Bimo, 2002. "PHP dan MySQL untuk Web". Andi Offset, Yogyakarta.

- Sutarman, 2003. "Konsep dasar Website” 